\title{
ASSESMENT BLUE ECONOMY: IMPLEMENTASI INTEGRATED MULTI-TROPIC AQUACULTURE (IMTA) PADA KAWASAN KIMBis CAKRADONYA DI BANDA ACEH
}

\author{
Armen Zulham ${ }^{1}$, Estu Sri Luhur ${ }^{1}$, Joni Haryardi ${ }^{2}$, dan Freshty Yulia Arthatiani ${ }^{1}$ \\ ${ }^{1}$ Balai Besar Penelitian Sosial Ekonomi Kelautan dan Perikanan \\ JI. KS. Tubun Petamburan VI Jakarta 10260 \\ Telp. (021) 53650162, Fax. (021)53650159 \\ ${ }^{2}$ Peneliti pada Pusat Penelitian dan Pengembangan Perikanan Budidaya Kelautan dan Perikanan \\ e-mail: keude_bing@yahoo.co.id \\ Diterima 3 Juli 2012- Disetujui 22 Nopember 2013
}

\begin{abstract}
ABSTRAK
Salah satu prinsip dari ekonomi biru (blue economy) adalah memanfaatkan limbah berbagai usaha kelautan dan perikanan pada masyarakat menuju zero waste. Tiga prinsip lain yang mendukung pencapaian zero waste adalah teknologi yang digunakan harus inovatif dan adaptif, usaha tersebut harus memiliki inklusi sosial dan mampu mendorong multiplier effect yang luas dalam perekonomian. Dengan empat prinsip tersebut pada tahun 2013, KIMBis Cakradonya di Banda Aceh melakukan implementasi ekonomi biru dengan menggunakan teknologi Integrated Multitropic Aquaculture (IMTA). Teknologi ini mengutamakan budidaya kepiting soka sebagai komoditas target, diintegrasikan dengan komoditas bandeng dan rumput laut sebagai komoditas non-target. Tulisan ini bertujuan untuk memberi gambaran hasil pelaksanaan implementasi prinsip ekonomi biru dengan menggunakan teknologi IMTA. Hasil implementasi menunjukkan bahwa kondisi perairan kawasan implementasi IMTA sangat baik untuk dikembangkan budidaya kepiting soka, rumput laut dan bandeng secara terpadu. Sementara itu, data pertambahan berat kepiting soka selama 45 hari adalah: 11 gram per ekor dengan tingkat kematian 10\%. Pertambahan berat rumput laut menunjukkan hasil yang sangat baik karena mengalami pertambahan 100\% dibandingkan dengan berat awal penanaman. Namun, ikan bandeng tidak mengalami pertumbuhan yang cukup baik bila dibandingkan dengan pertumbuhan nener bandeng dibesarkan di kolam pada umumnya. Penerapan prinsip Blue Economy pada budidaya kepiting soka berpotensi menghasilkan limbah cangkang kepiting sekitar 1 kuintal per hektar per hari, sehingga jika usaha ini berkembang sekitar 100 hektar akan terdapat potensi limbah yang dapat dimanfaatkan sebanyak 100 kuintal per hari (10 ton). Implementasi Blue Economy ini sangat bergantung pada tingkat partisipasi para pemangku kepentingan di luar satker litbang. Oleh sebab itu, hasil kegiatan ini mengusulkan perlu dilakukan sosialisasi lanjutan kepada SKPD dan masyarakat, termasuk enterpreneur agar level partisipasi mereka dalam kegiatan KIMBis berada pada level involvement. Dengan level partisipasi tersebut maka implementasi blue economy dapat memenuhi prinsip-prinsip minimize waste, inklusi sosial, teknologi inovatif dan adaptif serta memiliki multiplier effect yang luas.
\end{abstract}

Kata kunci: ekonomi biru, teknologi budidaya, multitropik terintegrasi, KIMBis, Banda Aceh

Abstract : Profile of Lobster Fishing Activity in Sadeng Coastal Area, Gunungkidul District. By Subhechanis Saptanto.

One of the principles of blue economy is the reuse of waste from marine and fisheries business towards zero waste. Three other principles that support zero waste is the technology used must be innovative and adaptive, business must have a social inclusion, and business should be able to push the vast multiplier effect in the economy. With these principles, KIMBis Cakradonya, Banda Aceh, in 2013 had implemented blue economy by using the technology of Integrated Multitropic Aquaculture (IMTA).This technology prioritizes soft-shelled crab as the commodity targetwhichis integrated with milkfish and seaweed as a non-targeted commodity. This paper aimed to illustrate the results of blue economy implementation principle by using IMTA technology. Results showed that the implementation of IMTA's marine conditions are excellent for cultivation soft-shelled crabs, seaweed and milkfish in an integrated manner. Meanwhile, data of weight gain of shelled crabs for 45 days is: 11 grams per head with 10\% mortality rate. Weight gain of seaweed showed excellent results due to the increase of $100 \%$ compared to the initial weight of the planting. Unfortunately, the weight of milkfish did not increase quite well compared to the growth of milkfish raised in ponds. Application of the blue economy principle on soft-shelled crab fishing has the potential crab shell waste about 1 quintal per hectare per day, so if business is growing about 100 acres there will be a potential waste as much as 100 quintals per day (10 tons). Implementation of blue economy is heavily dependent on participation level of stakeholders outside research and development work units. Therefore, the results of this activityneeds to be disseminated further socialization on SKPD and society, including entrepreneurs so that their participation in KIMBis activitycan reach the involvement level. With this level of participation, implementation of blue economycan fulfillthe four principles: minimize waste, social inclusion, innovative and adaptive technologies and extensive multiplier effect.

Keywords : blue economy, technology, integrated multi-tropic aquaculture, KIMBis, Banda Aceh 


\section{PENDAHULUAN}

Ekonomi biru (blue economy) dapat juga disebut sebuah konsep pengembangan usaha atau bisnis sektor Kelautan dan Perikanan secara terpadu yang ramah lingkungan. Konsep ekonomi biru dapat dikatakan setara dengan pendekatan pengembangan dan pengelolaan sumberdaya kelautan dan perikanan secara berkelanjutan (marine and fisheries sustainable development) yang bertujuan untuk meningkatkan pendapatan dan kesejahteraan masyarakat Kelautan dan Perikanan.

Akhir tahun 2013 ini, permintaan pasar terhadap kepiting soka terus meningkat, sementara kepiting soka bakalan dari alam terus menurun baik dari segi ukuran dan jumlah. Salah satu buyer Jepang (PTJ.C.Internasional) mengajukan kontrak kepada pembudidaya sebagai supplier kepiting soka ke Jepang dengan jumlah minimum 4 ton per bulan dengan harga Rp 120.000 per kg. Tawaran ini merupakan peluang dan tantangan bagi pembudidaya dan pemerintah Kota Banda Aceh dalam mengembangkan potensi lahan pesisir daerah ini dan perekonomian masyarakat kawasan KIMBis Cakradonya di Banda Aceh secara optimal.

Namun, pengembangan kegiatan tersebut di atas masih menghadapi beberapa kendala yang diantaranya masih rendahnya tingkat pendidikan (SDM), ketersediaan benih kepiting cangkang lunak yang berkurang dan mahal, keterbatasan dana dan akses permodalan, sumberdaya manusia profesional, lemahnya pendampingan dan pembinaan masyarakat, kurangnya prasarana pendukung pada pengusaha (Cold storage $-40^{\circ} \mathrm{C}$ ), serta rendahnya koordinasi dan implementasi peraturan terhadap segala aturan yang dapat menjadi jaminan untuk berlangsung sistem usaha dengan baik.

Selain itu, kondisi sumberdaya dan lingkungan akan rusak karena tidak dikelola oleh individu-individu yang bertanggung jawab dan profesional. Jika hal ini tidak diatasi, maka akan menambah sumber permasalahan sosial dan ekonomi di kawasan masyarakat kelautan dan perikanan. Salah satu solusi yang adaptif terhadap persoalan di atas adalah melakukan implementasi teknologi yang bersifat multiefek, inklusi sosial, inovatif dan adaptif minimize waste. Sementara itu untuk mereduksi persoalan-persoalan tata kelola kelautan dan perikanan serta tingkat keterlibatan masyarakat kelautan dan perikanan akan dilakukan pendampingan dan pengawalan oleh lembaga Klinik IPTEK Mina Bisnis (KIMBis) Cakradonya di Kota Banda Aceh.

Kegiatan pendampingan dan pelatihan budidaya Integrated Multi-Tropik Aquaculture (IMTA) dilakukan dengan memberi bimbingan teknis implementasi teknologi secara langsung kepada masyarakat dan mempromosikan teknologi tersebut kepada pengambil keputusan. Bimbingan teknis kepada masyarakat bertujuan untuk memahami teknologi yang dimaksud, sedangkan promosi tersebut dimaksudkan untuk menyebarkan teknologi tersebut ke seluruh daerah di Aceh melalui pengambil kebijakan. Budidaya multi tropik terintegrasi ini merupakan sistem budidaya yang memerlukan dukungan dari pemerintah daerah karena budidaya dengan teknologi IMTA ini mendorong keseimbangan dan saling menguntungkan dengan menggunakan komoditas-komoditas yang saling memanfaatkan relung dan nutrien serta aliran energi.

Prinsip budidaya multitropik terintegrasi adalah memanfaatkan limbah dari budidaya komoditas target (kepiting soka) menuju zero waste. Artinya, input pakan hanya akan diberikan kepada komoditas target yang mempunyai nilai ekonomis tinggi, sedangkan sisa pakan dan semua nutrien sisa budidaya akan dimanfaatkan komoditas level berikutnya yang secara kuantitatif jauh lebih banyak dari komoditas target (kepiting soka). Dengan demikian, biaya pakan untuk komoditas nontarget (bandeng dan rumput laut) adalah nol. Pada teknologi IMTA, fungsi komoditas non-target yang berperan sebagai pembersih limbah budidaya juga akan meningkatkan kelestarian lingkungan.

Secara ekonomi, komoditas non-target ini diharapkan juga akan mampu memberi multiplier effect yang besar pada perekonomian di kawasan tersebut. Dengan demikian, implementasi IMTA ini mendorong tersedianya lapangan kerja tambahan pada masyarakat, munculnya usaha pembuatan kontainer pemeliharaan kepiting pada masyarakat, munculnya potensi limbah baru yang dapat dimanfaatkan masyarakat untuk menghasilkan berbagai produk baru. Implementasi dan pengembangan budidaya IMTA di kawasan KIMBis Cakradonya akan memberikan harapan baru bagi masyarakat pembudidaya memulai usaha budaya kepiting, bandeng dan rumput laut secara terintegrasi untuk memperoleh pendapatan tambahan.

Untuk mempercepat implementasi teknologi ini kepada masyarakat (kelompok sasaran) dan pemangku kepentingan maka pengurus Klinik IPTEK Mina Bisnis (KIMBis) Cakradonya didukung oleh Balai Besar Penelitian Sosial Ekonomi Kelautan dan Perikanan (BBPSEKP) serta Pusat Penelitian dan Pengembangan Budidaya (P4B) Perikanan melaksanakan kegiatan Sosialisasi Peluang Pengembangan Usaha Budidaya Kepiting Soka dan Pengenalan Teknologi IMTA (Integrated Multi Tropic Aquaculture) di Kantor Wali Kota Banda Aceh dengan peserta berasal dari UPT, SKPD-SKPD Provinsi dan Kabupaten/Kota yang ada di Provinsi Aceh, pada bulan September 2013. Hal ini dilakukan karena salah satu fungsi dari KIMBis adalah menyebarkan teknologi hasil penelitian ke masyarakat.

\section{TUJUAN}

Tujuan tulisan ini adalah mendeskripsikan hasil implementasi blue economy teknologi budidaya multitropik terintegrasi (IMTA) di Banda 
Aceh. Implementasi ini diharapkan dapat memberi pemahaman tentang tantangan dan peluang implementasi blue economy kepada masyarakat perikanan.

\section{METODOLOGI}

\section{Jenis Komoditas}

Komoditas yang diimplementasikan dengan teknologi IMTA adalah kepiting soka sebagai komoditas target serta bandeng dan rumput laut sebagai komoditas non-target. Komoditas ini dipilih karena tersedia pada lokasi dan masyarakat sering membudidayakannya secara monokultur. Selain itu, komoditas ini dipilih karena menjadi program dari Dinas Kelautan dan Perikanan Provinsi Aceh untuk tahun 2014. Implementasi ini menggunakan lahan tambak budidaya air payau di daerah Lamjabat, Banda Aceh.

\section{Teknik Pelaksanaan}

Kegiatan implementasi teknologi IMTA ini menggunakan konsep partisipasi dengan melibatkan Dinas Kelautan Perikanan dan Pertanian Kota Banda Aceh, Dinas Kelautan dan Perikanan Provinsi, masyarakat, Pusat Penelitian dan Pengembangan Perikanan Budidaya (pemilik teknologi), Balai Besar Penelitian Sosial Ekonomi Kelautan dan Perikanan (fasilitator program), dan Balai Budidaya Laut Ujung Batee (pemilik teknologi). Selain itu, diikutsertakan juga mahasiswa Jurusan Kelautan dan Perikanan Universitas Syiah Kuala Banda Aceh sebagai mitra untuk membantu pemantauan.

Model partisipasi ini dilakukan melalui kegiatan identifikasi usaha kelautan dan perikanan yang telah menerapkan prinsip blue economy. Identifikasi ini menghasilkan usaha pada masyarakat kelautan dan perikanan di Banda Aceh yang menerapkan prinsip Blue Economy, namun limbah dari usaha yang dilakukannya belum dimanfaatkan secara optimal. Budidaya kepiting soka merupakan salah satu alternatif yang dipilih dalam pelaksanaan program ini.

Implementasi teknologi IMTA di tambak dilakukan setelah kelompok sasaran (masyarakat pembudidaya kepiting soka) mengerti dan memahami modul IMTA yang diperkenalkan. Setelah itu, kelompok sasaran melakukan implementasi IMTA di tambak yang sudah ditentukan dan didampingi oleh instruktur pemilik teknologi dan fasilitator serta pengurus KIMBis Cakradonya Kota Banda Aceh yang selanjutnya berfungsi mendampingi dan memonitor perkembangan implementasi IMTA tersebut.

Untuk memberikan gambaran kepada kelompok sasaran mengenai perbedaan metode implementasi IMTA dengan usaha budidaya tambak yang biasa dilakukan masyarakat maka pengamatan juga dilakukan di kawasan non-IMTA. Parameter pengamatan utama yang diamati secara reguler dalam implementasi tersebut terdiri dari pertumbuhan dan survival rate kepiting cangkang lunak, rumput laut, dan bandeng serta kualitas air tambak. Data lain adalah tingkat partisipasi berbagai pemangku kepentingan dalam program ini.

\section{Tempat dan Waktu}

Implementasi IMTA dilakukan pada tambak milik masyarakat di Desa Lamjabat, Kota Banda Aceh. Waktu pelaksanaan dilakukan pada 6 September 2013 sampai dengan pertengahan November 2013. Selama waktu tersebut diamati berbagai parameter fisik dan sosial ekonomi yang terkait dengan tingkat partisipasi dan peluang investasi dari implementasi IMTA tersebut.

\section{GAMBARAN IMTA}

Kegiatan polikultur dan multitropik yang lebih adaptif dan aplikatif ini dilaksanakan dengan mendorong partisipasi Pusat Penelitian dan Pengembangan Perikanan Budidaya Kelautan dan Perikanan serta Balai Budidaya Laut Ujung Batee untuk berpartisipasi dalam program ini. Implementasi IMTA ini dapat dilakukan dalam masyarakat karena teknologi budidaya udang, bandeng, nila, tiram dan rumput laut secara monokultur sudah sangat berkembang di masyarakat. Dengan demikian, pengembangan teknologi ini dalam masyarakat diharapkan tidak menghadapi kendala yang cukup berarti.

Sistem budidaya polikultur dan multitropik telah terbukti dapat menciptakan ekosistem dalam tambak yang seimbang (Chopin, 2006) dan mengurangi pengaruh penggunaan bahan an-organik dan bahan kimia lain dari pakan dan obat-obatan yang berbahaya bagi manusia dan biota dalam budidaya serta memberikan keuntungan ekonomi yang fantastis dengan net benefitcost ratio sebesar 5,41 (DJPB, 2012).

Menurut Hirata (2002), pengembangan budidaya masa depan adalah budidaya yang memberi hasil yang tinggi, biaya operasional rendah dan ramah lingkungan yang disebut sebagai blue aquaculture. Jadi pendekatan intensifikasi budidaya dengan pendekatan ekologi sudah menjadi tuntutan masyarakat lokal, nasional dan internasional (FAO, 2000).

Prinsip multitropik akuakultur adalah zero waste, artinya input pakan hanya akan diberikan pada komoditas target yang mempunyai nilai ekonomis tinggi, sedangkan sisa pakan dan semua nutrien sisa budidaya akan dimanfaatkan komoditas level berikutnya yang secara kuantitatif jauh lebih banyak dari komoditas target (bandeng, nila, rumput laut dan tiram). Komoditas target dan bukan target ini diharapkan akan memberi multiplier effect dalam perekonomian; menumbuhkan kegiatan baru sehingga mendorong dibukanya lapangan kerja baru dalam masyarakat. 
Fungsi komoditas non-target lainnya adalah sebagai pengendali dampak dari limbah budidaya dan akan mendorong meningkatkan kualitas lingkungan (Haris, 2009). Model sistem budidaya yang minim limbah (zero waste), secara teknis dapat dipelajari pada tampilan Gambar 1 dan Gambar 2.

\section{USAHA BUDIDAYA KEPITING SOKA}

\section{Struktur Ongkos Usaha Budidaya Kepiting Soka}

Hasil identifikasi dari kegiatan kelompok sasaran KIMBis Cakradonya Kota Banda Aceh menunjukkan bahwa budidaya kepiting soka cangkang lunak merupakan salah satu kegiatan andalan ekonomi masyarakat dapat berkembang dengan baik. Hasil produksi budidaya kepiting cangkang lunak dari Kota Banda Aceh sangat diminati oleh buyer-buyer lokal yang berasal dari Medan, Jakarta, Surabaya, dan Bali dan juga pembeli mancanegara, seperti Amerika, Jepang, Hongkong, Taiwan, Malaysia dan Thailand. Hal ini disebabkan oleh tingginya kualitas (kadar air $\leq 10 \%$ ) dan rasa kepiting soka yang khas dan tidak sama dengan hasil produksi pada kawasan lain di Indonesia.

Analisis usaha Budidaya kepiting Soka di Banda Aceh dapat dipelajari dari Tabel 1. Tabel tersebut terdiri dari 4 bagian utama, yaitu: Investasi, Penerimaan, Biaya Operasional dan Biaya Tetap dari satu hektar usaha budidaya per tahun.

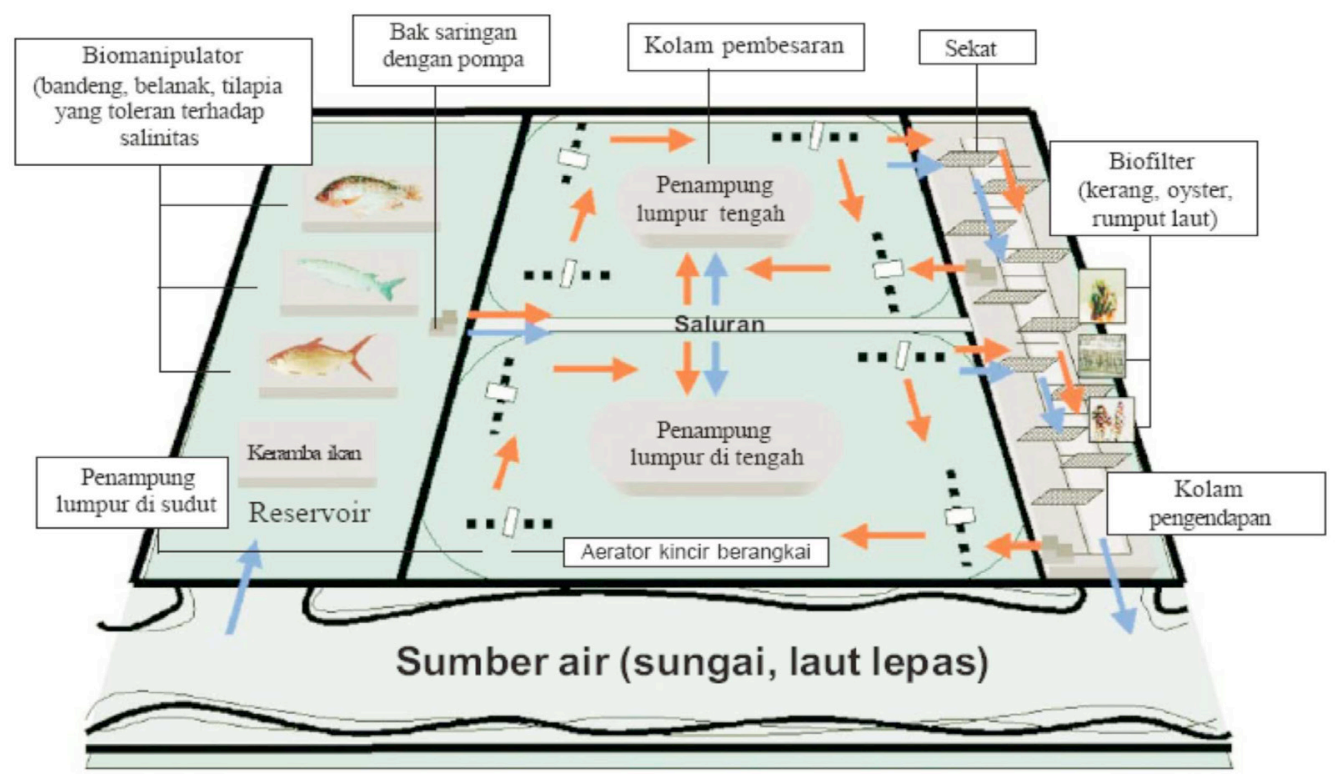

Gambar 1. Sistem Budidaya Perikanan yang Menerapkan Prinsip Blue Economy Sumber: FAO, 2009

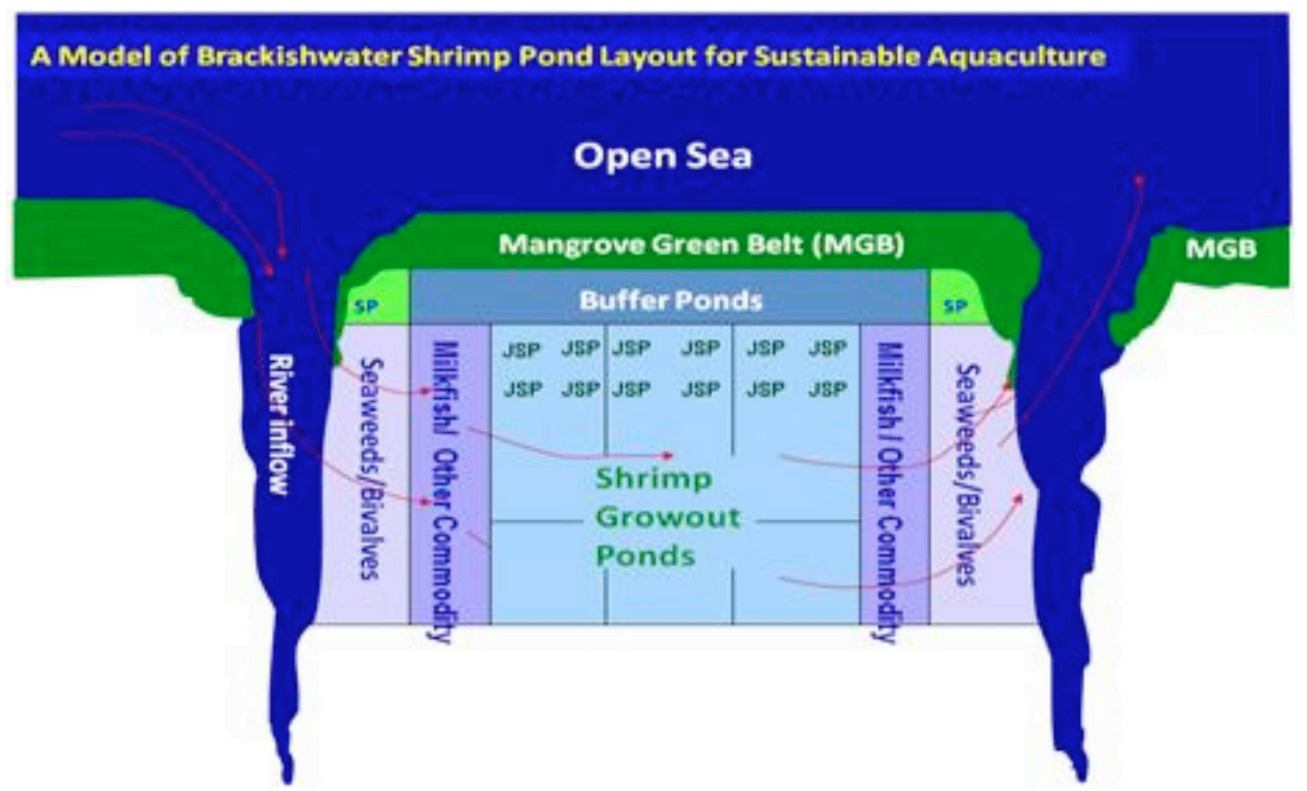

Gambar 2. Sistem Budidaya Perikanan Air Payau dengan Prinsip Blue Economy 
Tabel 1. Analisis Usaha Budidaya Kepiting Soka Per Hektar Per Tahun.

\begin{tabular}{lcrrr}
\multicolumn{1}{c}{ Investasi } & Umur Ekonomis & Jumlah (unit) & Harga satuan (Rp) & Nilai (Rp) \\
\hline A. Investasi: & & & & \\
Rakit (unit) & 10 tahun & 40 & 2.500 .000 & 100.000 .000 \\
Basket (unit) & 10 tahun & 3.600 & 10.000 & 36.000 .000 \\
Frezer (unit) & 7 tahun & 6 & 5.000 .000 & 30.000 .000 \\
Kulkas Pembeku (unit) & 7 tahun & 3 & 2.500 .000 & 7.500 .000 \\
Gunting (unit) & 5 bulan & 5 & 25.000 & 125.000 \\
Timba (unit) & 7 tahun & 10 & 10.000 & 100.000 \\
Pisau (unit) & 3 tahun & 5 & 200.000 & 1.000 .000 \\
Jembatan Kayu (meter) & 5 tahun & 90 & 100.000 & 9.000 .000 \\
Rumah Jaga (Unit) & 5 tahun & 4 & 15.000 .000 & 60.000 .000 \\
Timbangan (unit) & Stahun & 5 & 500.000 & 2.500 .000 \\
Becak Motor (unit) & 5 tahun & 2 & 5.000 .000 & 10.000 .000 \\
Motor (unit) & 8 tahun & 1 & 15.000 .000 & 15.000 .000 \\
Palu (unit) & 10 tahun & 5 & 30.000 & 150.000 \\
Gergaji (unit) & 5 tahun & 3 & 160.000 & 480.000 \\
Tali & 2 tahun & 1 & 1.000 .000 & 1.000 .000 \\
\hline \multicolumn{1}{c}{ Jumlah } & & & 272.855 .000
\end{tabular}

\section{B. Penerimaan:}

\begin{tabular}{|c|c|c|c|}
\hline Kepiting Soka (kg) & 21.600 & 110.000 & $2,376,000,000$ \\
\hline Jumlah & & & $2,376,000,000$ \\
\hline \multicolumn{4}{|l|}{ C. Biaya Operasional: } \\
\hline Bibit (kg) & 28.800 & 50.000 & 1.440.000.000 \\
\hline Pakan (kg) & 6.000 & 10.000 & 60.000000 \\
\hline Tenaga Kerja (orang) & 6 & 25.200.000/tahun & 151.200 .000 \\
\hline Biaya Makan Minum (Rp) & 36 & 300.000 & 10.800 .000 \\
\hline Jumlah & & & $1,662,000,000$ \\
\hline \multicolumn{4}{|l|}{ D. Biaya Tetap: } \\
\hline Sewa Lahan & 12 & 1.000 .000 & 12.000 .000 \\
\hline Biaya Listrik & 12 & 3.000 .000 & 36.000 .000 \\
\hline BBM & 12 & 800.000 & 9.600 .000 \\
\hline Cicilan Usaha/ Modal & 12 & 2.500 .000 & 30.000 .000 \\
\hline Biaya Telepon & 12 & 1.000 .000 & 12.000 .000 \\
\hline Jumlah & & & 99.600 .000 \\
\hline E. Jumlah Biaya (C + D) & & & 1.761 .600 .000 \\
\hline F. Keuntungan Usaha (B - E) & & & 614.400 .000 \\
\hline \multicolumn{4}{|l|}{ G. Analisis Usaha: } \\
\hline$-P P$ & & & 2.25 \\
\hline - $R / C$ Ratio & & & 1.35 \\
\hline - ROI & & & $225 \%$ \\
\hline
\end{tabular}

Sumber: Data Primer (diolah), 2013 
Berdasarkan analisis usaha diatas dapat diketahui bahwa keuntungan usaha yang diperoleh adalah sebesar Rp. 614.400.000/tahun yang didapatkan dari pengeluaran usaha dikurangi dengan penerimaan usaha. Penerimaan usaha tiap tahunnya Rp. 2.376.000.000 yang diperoleh dari rata-rata produksi tiap bulanya yang mencapai $1.800 \mathrm{~kg} /$ bulan dengan harga rata-rata kepiting Rp. 110.000. Pengeluaran usaha terdiri atas komponen biaya variabel dan biaya tetap.

Total biaya variabel yang diperlukan setiap tahunya sebesar $\mathrm{Rp}$ 1.662.000.000 dengan biaya tetap sebesar Rp. 99.600.000. Nilai Investasi yang diperlukan sebesar Rp. 272.855.000. Payback Period untuk biaya investasi akan dicapai setelah 0,86 tahun usaha atau sekitar 11 bulan setelah usaha dijalankan. Tingkat pengembalian investasi dapat dilihat dari nilai ROI (return on investment) yaitu sebesar $225 \%$. Nilai penerimaan atas biaya usaha dapat dilihat dari $R / C$ ratio sebesar 1.35 yang menunjukkan bahwa setiap rupiah biaya yang dikeluarkan akan menghasilkan penerimaan sebesar 1.35 Rupiah.

Dari total biaya investasi Rp. 272,8 Juta, biaya investasi terbesar adalah untuk biaya pembuatan rakit dari paralon (36,7\%), dan bangunan jaga dan opreasional budidaya kepiting soka (21,9 \%). Biaya investasi lain adalah freezer untuk mempertahankan kualitas kepiting soka hasil panen sekitar (11,0 \%).

Perlu dicatat, biaya operasional budidaya kepiting Soka di Banda Aceh cukup tinggi sekitar Rp. 1.662 juta per hektar per tahun. Biaya operasional ini mencapai sekitar $70 \%$ dari penerimaan usaha budidaya kepiting soka per tahun. Jika biaya tetap digabung dengan biaya operasional (Rp. 1.761,6 Juta), maka biaya yang dikeluarkan untuk usaha ini cukup tinggi mencapai $74 \%$ dari penerimaan. Tingginya biaya operasional dan biaya tetap tersebut, memberi indikasi bahwa usaha ini tidak bisa dikelola secara konvensional.

Dengan kata lain usaha ini harus dikelola sebagai sebuah bisnis usaha dengan manajemen yang profesional agar cash - flow dari usaha tersebut selalu sehat. Pengelolaan dengan manajemen yang profesional ini diharapkan juga mampu memanfaatkan limbah fisik yang dihasilkan dari kepiting soka, sehingga menghasilkan produk baru yang akan menambah sumber pendapatan, dan pemanfaatan limbah ini merupakan konsep blue economy.

Sebagai informasi, pasar untuk kepiting soka ini sangat terbuka dan sistim distribusinya sudah berkembang dengan baik dengan memanfaatkan transportasi udara. Harga kepiting soka (FOB) Banda Aceh rata-rata Rp. 110.000 per kg dan setiap satu kuintal dikenakan biaya handling dan gudang sebesar Rp. 30.000. Dengan struktur harga dan biaya seperti itu maka kepiting soka dari Banda Aceh dapat dikirim ke Surabaya.

\section{Implementasi Teknologi IMTA}

Uraian diatas telah menunjukkan bahwa secara ekonomis usaha budidaya kepiting soka tersebut sangat layak. Namun, usaha ini harus dikelola dengan manajemen yang profesional. Sebagai usaha yang potensial maka pada usaha ini coba diperkuat dengan teknologi IMTA. Secara teknis, teknologi ini diperkenalkan untuk memanfaatkan limbah yang dihasilkan dari budidaya kepiting soka dalam perairan dan potensi limbah yang dihasilkan dalam mendorong proses moulting. Kegiatan implementasi IMTA dilakukan secara bertahap, yaitu sosialisasi pelaksanaan IMTA, pemasangan atau instalasi model IMTA, dan penanaman komoditas kepiting, bandeng dan rumput laut.

\section{Sosialisasi Pelaksanaan IMTA}

Sosialisasi pelaksanaan IMTA dilakukan terhadap kelompok sasaran kepiting soka di daerah Desa Lamjabat, Kecamatan Meuraxa, Kota Banda Aceh. Kelompok ini telah terbentuk sejak program rekonstruksi pembangunan pasca Tsunami di Aceh. Kelompok ini menjadi mitra untuk menyebarkan teknologi hasil litbang kelautan dan perikanan di Banda Aceh.

Sosialisasi pada kelompok kepiting soka ini dilakukan sangat detil dengan bahasa yang mudah dimengerti sehingga kelompok ini dapat menggunakan modul yang telah disiapkan. Sosialisasi dengan kelompok sasaran ini lebih teknis terhadap implementasi IMTA. Materi kegiatan dalam bentuk modul atau petunjuk teknis (JUKNIS) IMTA dan logbook IMTA dibagikan dan dijelaskan kepada koo perator peserta dalam presentasi dan tinjauan lapangan. JUKNIS merupakan panduan yang berisi alat dan bahan serta prosedur melakukan implementasi IMTA di tambak. Sedangkan Buku Logbook berfungsi sebagai pencatat seluruh data dan informasi komoditas dan kualitas air yang diperoleh selama proses implementasi dilakukan.

Dalam sosialisasi dengan kelompok sasaran, semua tahapan dan teknik pemasangan dijelaskan, agar pembudidaya kepiting soka mengerti dan memahami IMTA secara komprehensif dan mampu melakukannya dengan baik (Gambar 3). Materi implementasi IMTA disampaikan dengan bentuk presentasi teori singkat, diskusi kelompok, serta praktek di lapangan. Penerapan Teknologi IMTA menggunakan komoditas tambahan ikan bandeng dan rumput laut.

Dalam pelatihan dan pendampingan implementasi IMTA di KIMBis Cakradonya, partisipasi peserta sangat dipengaruhi kemampuan instruktur dalam memotivasi, membangun tingkat kepercayaan peserta terhadap pekerjaan yang diarahkan oleh instruktur. Instruktur harus mampu menunjukkan keterlibatannya secara optimal dalamkegiatanimplementasi (penguasaan materi, persiapan kegiatan dan implementasi). 
Upaya yang ditunjukkan oleh instruktur ini memberi dampak postif dalam meningkatkan partisipasi peserta dalam kegiatan implementasi IMTA.

Sosialisasi IMTA juga dilakukan kepada perwakilan Satuan Kerja Perangkat Daerah (SKPD) kelautan dan perikanan kabupaten/kota seluruh Aceh. Tujuannya adalah untuk memberi motivasi dalam memanfaatkan tambak yang terbengkalai (idle) yang ada saat ini dan belum dimanfaatkan secara maksimal sehingga IMTA dan budidaya kepiting soka dapat menjadi program pembangunan kabupaten kota di Provinsi Aceh.

\section{Pemasangan Instalasi Model IMTA dan Penanaman Komoditas Target dan Non-Target}

Pemasangan atau instalasi model IMTA dilakukan oleh para peserta pelatihan dibantu oleh teknisi dan pengurus KIMBis Cakradonya Kota Banda Aceh. Dalam implementasi IMTA diperlukan alat, bahan dan prosedur pekerjaan sebagai berikut.
Bahan utama terdiri dari bibit kepiting jantan atau betina yang belum matang gonad dengan berat $70-120$ gram; bibit rumput laut jenis gracilaria; benur udang putih (Penaues javanicus) tokolan dan nila, pakan (kulit sapi/ trash fish); tambak sekitar 0,1 ha; jaring/ waring ukuran $5 \mathrm{~m} \times 6 \mathrm{~m}$; tiang pancang/ patok kayu; kontainer kepiting; paralon; anco. Alat bantu yang diperlukan adalah: Gunting, Lem alteco, Gergaji, Palu, Paku, Tali, Ember.

Prosedur kerja implementasi IMTA terdiri dari: (a)Petak tambak Tambak 0,1 ha di buat pen/jaring tancap dengan ukuran $5 \mathrm{~m} \times 10 \mathrm{~m} \times 1,5 \mathrm{~m}$ sebanyak 2 petak. Ukuran mata waring /jaring yang digunakan sebesar 0,3 inchi; (b)4 paralon $3 / 4$ inchi dipasang di dalam waring/pen sebagai floating dan tempat pemasang box kepiting; (c)Jumlah padat tebar kepiting di setiap perlakuan adalah \pm 20 ekor/m2 dengan berat 80- $120 \mathrm{gr}$ per box. Untuk bibit nila di-stock dengan padat tebar $3-4$ ekor $/ \mathrm{m}^{2}$ ukuran $3-4 \mathrm{~cm}$, sedangkan untuk padat tebar rumput laut ditebar di dasar tambak

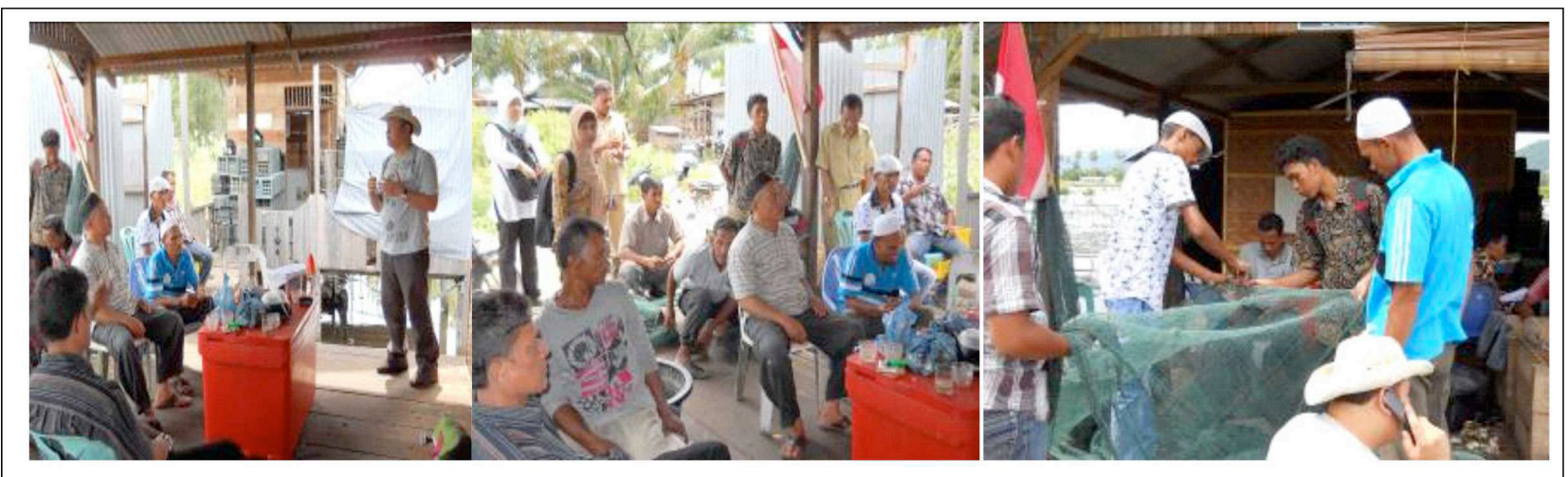

Gambar 3. Sosialisasi Materi IMTA di Lapangan dan Praktek Pembuatan Jaring Tancap pada Implementasi IMTA pada KIMBis Cakradonya di Banda Aceh.

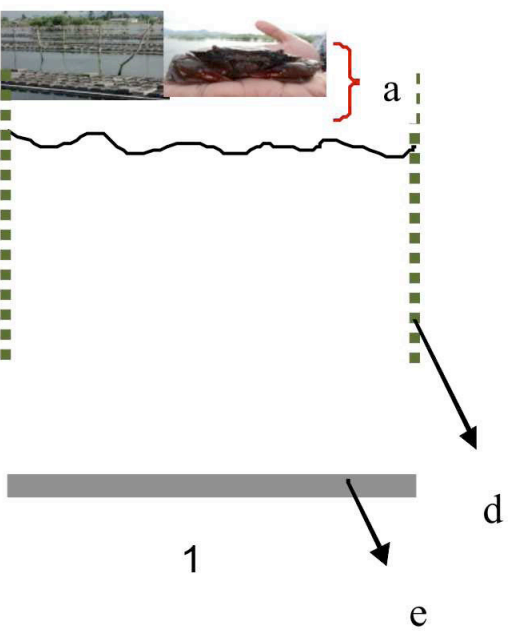

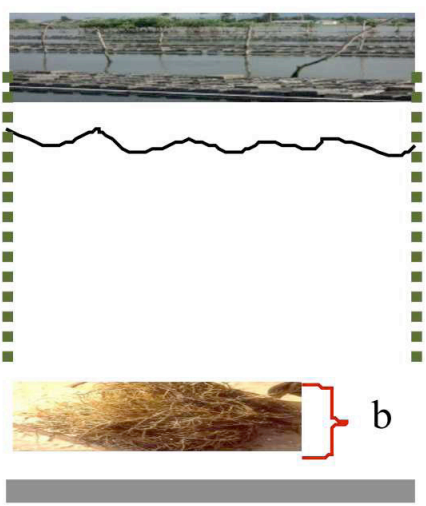

2

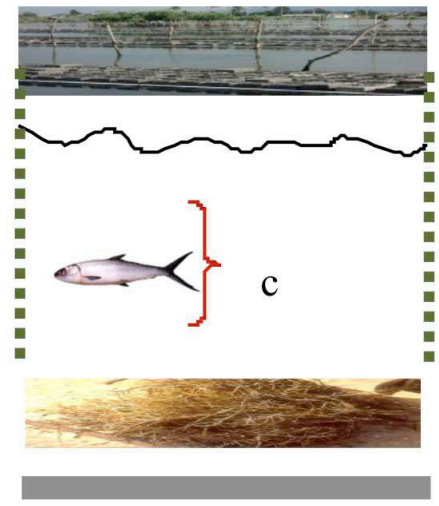

3

Keterangan:

a : kepiting; b : rumput laut; c : bandeng; d : jaring tancap; e : dasar tambak

Gambar 4. Ilustrasi Desain IMTA 
dengan kepadatan 50 kg (asumsi 1 ton/ ha); (d) Sebelum dimasukkan kedalam box soft sheel, kaki renang atau capit kepiting akan diamputasi; (e) Kepiting diletakkan satu ekor per box hitam pada pagi hari jam 05.00 06.00 WIB; (f) Pakan yang akan diberikan sebanyak 3-5\% dari total biomass atau setiap 2 hari sekali pada sore hari; (g) Pengecekan/kontrol dilakukan secara rutin dan setiap pagi, siang dan malam hari yang bertujuan untuk memonitor kepiting yang mati, sakit dan panen; (h) Panen dilakukan pada kepiting yang sudah berganti kulit/cangkang (moulting) dan dipindahkan ke dalam air tawar selama 1 jam untuk mencegah terjadi proses pengerasan kembali.

Pemasangan jaring dilakukan untuk membantu mempermudah pengamatan dan pencatatan yang dilakukan oleh kooperator terhadap komoditas yang dipelihara dengan teknik IMTA. Jenis komoditas yang dipelihara dalam kegiatan IMTA terdiri dari kepiting soka, ikan bandeng dan rumput laut jenis Grassilaria sp.
Tahap berikutnya adalah pengamatan selama proses budidaya berlangsung dilakukan untuk monitoring kualitas air dan kelangsungan hidup komoditas budidaya. Untuk data sosial ekonomi akan dilakukan pada tahap akhir kegiatan dan akan dilakukan penghitungan secara rinci terhadap jumlah modal yang telah dikeluarkan dan jumlah pendapatan yang diterima selama proses implementasi berlangsung.

\section{Hasil Pelaksanaan Implementasi IMTA}

Kegiatan implementasi IMTA di KIMBis Cakradonya Kota Banda Aceh dilaksanakan selama 45 hari sesuai dengan masa budidaya rumput dan pola panen kepiting soka cangkang lunak 15 - 21 hari setelah dimasukan ke dalam crab box. Pengamatan, penjagaan model implementasi IMTA dan pengambilan data dilakukan oleh kooperator bersama dengan pengurus KIMBis Cakradonya. Pencatatan terhadap kualitas kawasan implementasi (Suhu, Salinitas, pH dan DO (oksigen

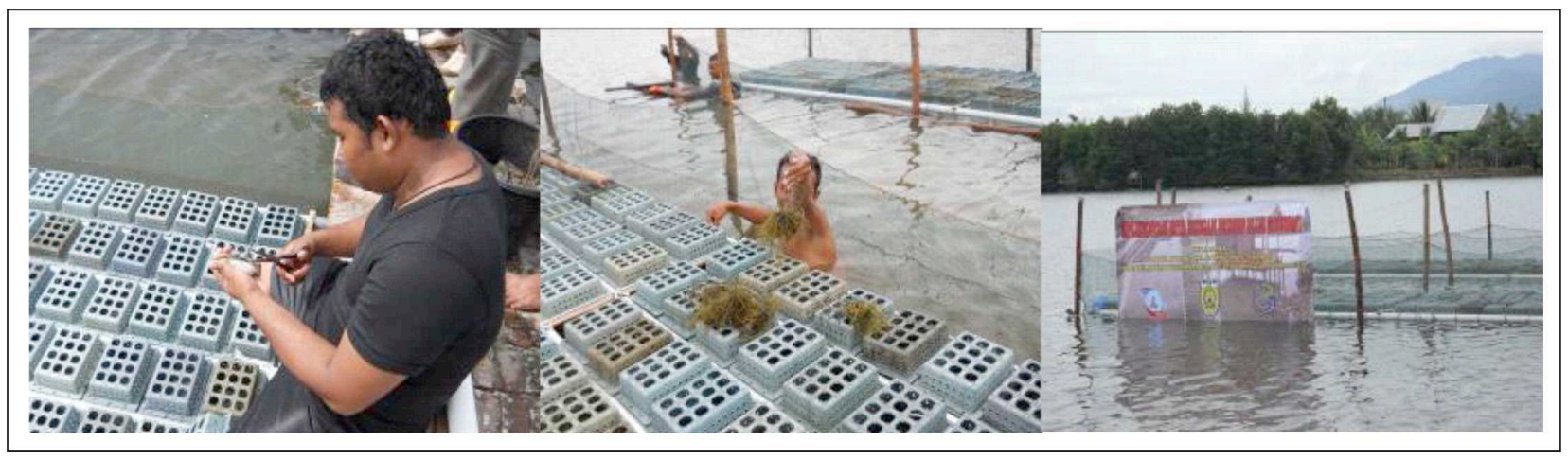

Gambar 5. Perakitan Teknologi Model IMTA dan Penebaran Kepiting, Bandeng dan Rumput Laut

Padat tebar kepiting dari setiap implementasi berjumlah 144 ekor dengan berat antara 80 - $100 \mathrm{gr}$ per ekor. Untuk ikan bandeng dengan padat tebar nener bandeng sejumlah 150 ekor per implementasi dengan panjang rata-rata 1 inchi per ekor, sedangkan padat tebar rumput laut $\pm 10 \mathrm{~kg}$ per implementasi IMTA. Semua bakalan kepiting soka, rumput laut dan bandeng disediakan oleh kooperator. Hal ini merupakan salah satu bentuk kontribusi kooperator dalam mendukung terlaksananya kegiatan implementasi IMTA di KIMBis Cakradonya di Kota Banda Aceh. terlarut)) di lakukan setiap hari (pagi dan sore) dan di cetak ke dalam logbook IMTA yang hasilnya ditunjukkan oleh Tabel 2 dan Gambar 6.

Data dan infromasi yang diperoleh menunjukkan bahwa kondisi perairan kawasan Implementasi IMTA sangat baik untuk dikembangkan budidaya kepiting cangkang lunak, rumput laut dan bandeng secara terpadu terlihat pada Tabel 2. Dalam tabel tersebut pembanding kualitas untuk kawasan IMTA diambil dari hasil penelitian ACIAR tahun 2001 untuk mengetahui

Tabel 2. Hasil Pengamatan Kualitas Air IMTA selama masa percobaan, September - Oktober 2013.

\begin{tabular}{lrr}
\multicolumn{1}{c}{ Parameter Kualitas Air } & \multicolumn{1}{c}{ Nilai } & ACIAR 2001 \\
\hline Suhu $\left({ }^{\circ} \mathrm{C}\right)$ & $24.00-31.53$ & $28-32$ \\
Salinitas (ppt) & $16.00-36.00$ & $15-25$ \\
pH & $7.60-8,67$ & $7.5-8.5$ \\
DO $(\mathrm{mg} / \mathrm{l})$ & $5.30-22.65$ & $3-9$ \\
\hline
\end{tabular}

Sumber: Data Primer (diolah), 2013 


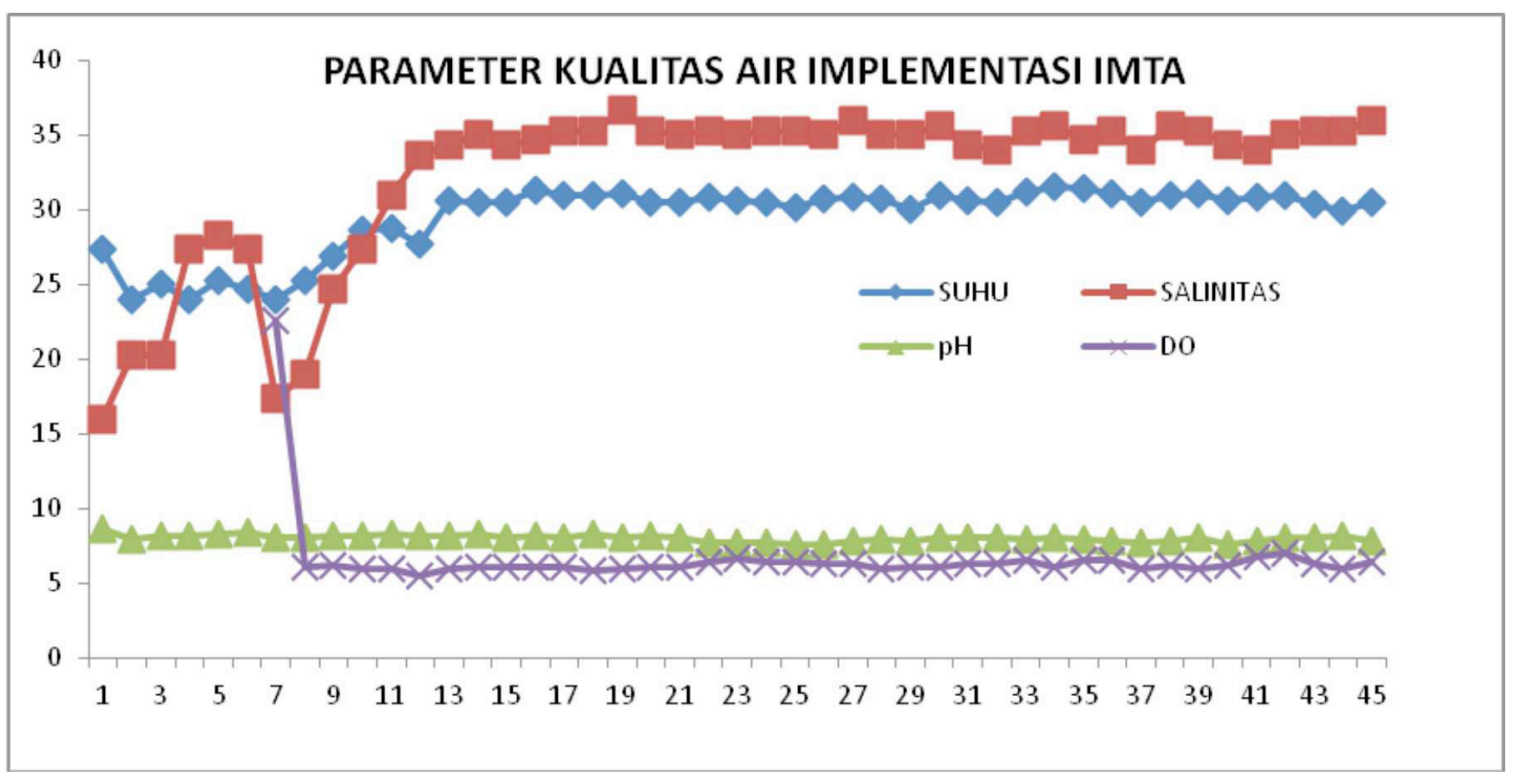

Gambar 6. Tren Grafik Kualitas Air pada Implementasi IMTA di Lamjabat Selama 45 Hari.

kelayakan lahan pengembangan IMTA dengan komoditas pengembangan udang. Artinya jika parameter yang diperoleh dari hasil pengamatan budidaya kepiting cangkang lunak relatif sedikit tinggi atau sama, maka itu menunjukkan bahwa biota yang lebih kuat seperti kepiiting, bandeng dan rumput laut dapat tumbuh dengan baik di lokasi tersebut.

Pada akhir periode pemeliharaan, dicatat berat awal dan dan berat akhir kepiting soka, bandeng dan rumput laut dalam implementasi IMTA. Perkembangan berat pada Tabel 3 merupakan perkembangan selama 45 hari masa pemeliharaan.

Selain didukung oleh data kualitas air, data pertambahan berat (Tabel 3) dari kepiting soka juga menunjukkan angka yang dapat diterima, yaitu 11 gram per ekor dengan Tingkat Kematian 10\%. Hal sesuai dengan informasi dan data yang diperoleh pembudidaya bahwa pertambahan berat dari kepiting soka cakang lunak umum 5-10\% dari berat awal kepiting soka.

Untuk pertumbuhan ikan bandeng yang dipelihara selama 45 hari tidak mengalami pertumbuhan yang cukup baik bila dibandingkan dengan pertumbuhan nener bandeng dibesarkan di kolam umumnya. Hal ini mungkin disebabkan ikan bandeng tidak bisa bebas mencari pakan tambahan karena tumbuh dalam lingkaran jaring. Namun pertumbuhan yang tidak memuaskan dapat disebabkan oleh nener yang dipelihara bukan dari kualitas unggul.

Jika dilihat pada Tabel 3, pertumbuhan berat rumput laut selama 45 hari mengalami pertambahan $100 \%$ dibandingkan dengan berat awal penanaman. Hal ini menunjukkan bahwa kawasan implementasi IMTA mempunyai tingkat kesuburan yang tinggi.

\section{Tingkat Partisipasi dalam Implementasi IMTA}

Tingkat partisipasi dalam implementasi IMTA ini pada dasarnya mempelajari keikutsertaan dari berbagai pemangku kepentingan (Dinas Kelautan Perikanan dan Pertanian Kota Banda Aceh, Dinas Kelautan dan Perikanan Provinsi Aceh, Balai Budidaya Laut Ujung Batee, Universitas Syiah Kuala) sebagai pihak luar dalam menyukseskan dan mengembangkan teknologi IMTA pada kawasan tersebut. Pada prinsipnya, partisipasi tersebut untuk melihat keberlanjutan dan pengembangan usaha dari hasil implementasi teknologi tersebut melalui program dalam pengembangan ekonomi masyarakat.

Tabel 3. Pertambahan Berat Komoditas Implementasi IMTA.

\begin{tabular}{lrr}
\multicolumn{1}{c}{ Jenis Komoditas IMTA } & Berat Awal $\left(\mathbf{W}_{\mathrm{o}}\right)$ & Berat Akhir $\left(\mathbf{W}_{\mathrm{t}}\right)$ \\
\hline Kepiting 80 - 100 gram & $\pm 50,6 \mathrm{gr}$ & $\pm 59,7 \mathrm{gr}$ \\
Ikan Bandeng 5 - 10 gr per ekor & $\pm 6 \mathrm{gr}$ & $\pm 20 \mathrm{gr}$ \\
Rumput Laut (Grassilaria sp) & $5 \mathrm{~kg}$ & $10 \mathrm{~kg}$ \\
\hline
\end{tabular}

Sumber: Data Primer (diolah), 2013 
Tabel 4. Tingkat Partisipasi Pemangku Kepentingan Terhadap Program IMTA di Lamjabat, Kota Banda Aceh Tahun 2013.

\begin{tabular}{clc} 
No. & \multicolumn{1}{c}{ Pemangku Kepentingan } & Level Partisipasi \\
\hline 1. & Dinas Kelautan dan Perikanan Provinsi Aceh & Involvement \\
2. & Dinas Kelautan Perikanan dan Pertanian Kota Banda Aceh & Engagement \\
3. & Masyarakat & Engagement \\
\hline
\end{tabular}

Terdapat berbagai tingkat partisipasi dalam pembangunan seperti yang disebutkan Pretty (1995). Namun, pada tingkat awal tingkat partisipasi tersebut menurut Syahyuti (2011) dapat dilihat sebagai suatu level partisipasi dalam bentuk: engagement (yang didefinisikan sebatas keterlibatan dalam pelaksanaan program) dan involvement (yang didefinisikan sebagai ikut berkontribusi dalam pelaksanaan program). Tabel 4 memberi gambaran tentang partisipasi dari pihak luar dalam program IMTA tersebut.

Tingkat partisipasi dasar tersebut menunjukkan implementasi teknologi IMTA tersebut hanya akan berhasil jika Dinas Kelautan dan Perikanan Provinsi Aceh benar-benar memegang komitmennya dalam pengembangan budidaya kepiting soka dengan teknologi IMTA. Hal ini dapat dilakukan karena dalam program Dinas Kelautan dan Perikanan Provinsi terdapat rencana pengembangan budidaya kepiting soka secara luas.

Sebaliknya pada Dinas Kelautan Perikanan dan Pertanian Kota Banda Aceh tidak terdapat rencana yang konkret tentang pengembangan budidaya kepiting soka. Partisipasi mereka hanya sebatas mengharapkan akan datang proyek dari Pusat jika ikut serta dalam program KIMBis. Kondisi yang sama ditunjukkan juga oleh masyarakat. Bagi masyarakat usaha ini dilihat memerlukan modal yang besar agar dapat berkembang.

Jika tingkat partisipasi masyarakat dapat didorong pada level partisipasi involvement maka pada usaha budidaya ini akan muncul potensi limbah yang cukup banyak, yaitu \pm 1 kuintal cangkang kepiting per hari per hektar tambak. Dengan demikian, jika usaha ini dapat dikembangkan sekitar 100 hektar maka akan tersedia 100 Kuintal (10 ton) cangkang kepiting soka per hari di Banda Aceh. Jumlah ini cukup ekonomis untuk mendirikan satu unit usaha baru yang dapat mengolah cangkang kepiting soka menjadi citosan yang merupakan bahan baku bagi industri farmasi.

\section{KESIMPULAN}

Implementasi IMTA pada kawasan KIMBis Cakradonya memberi dua informasi penting. Informasi pertama terkait penerapan teknologi tersebut di perairan. Secara teknis, implementasi teknologi IMTA tersebut memerlukan modifikasi terkait dengan arus air dalam tambak dan kedalaman tambak. Modifikasi teknologi harus dilakukan pada tambak yang memiliki hamparan yang luas.
Pada skala massal, penerapan teknologi IMTA ini memerlukan pengawalan yang intensif karena hal ini terkait dengan cara pemberian pakan pada kepiting dan teknik moulting. Pendampingan ini untuk meningkatkan solvabilitas dari usaha budidaya tersebut.

Tingkat partisipasi para pemangku kepentingan dalam implementasi blue economy menjadi prasyarat utama. Partisipasi itu harus pada tingkat involvement karena pengembangan secara luas teknologi IMTA dengan kepiting soka sebagai komoditas target akan menghasilkan limbah dalam jumlah yang besar sehingga memerlukan keikutsertaan enterpreneur dalam memanfaatkan limbah tersebut. Peran enterpreneur pada budidaya ini diperlukan untuk menghasilkan produk baru sekaligus dapat mendorong pengembangan ekonomi masyarakat.

Jika tingkat partisipasi tersebut hanya pada katagori engagement maka teknologi dan pengembangan komoditas budidaya tersebut di Banda Aceh tidak akan berkembang. Untuk mendorong partisipasi pada tingkat involvement diperlukan inovasi kebijakan yang terkait dengan kebijakan pengembangan budidaya tersebut, sosialisasi yang terkait dengan manfaat teknologi IMTA dan budidaya kepiting soka.

Dengan demikian, budidaya kepiting soka dan keberhasilan pengembangan teknologi IMTA tersebut akan berhasil jika peran dari seluruh pemangku kepentingan tersebut berada pada level partisipasi involvement. Pengembangan teknologi dan budidaya tersebut didukung oleh dukungan permodalan dari lembaga keuangan. Hal ini dapat dilakukan karena indikator ekonomi tentang usaha budidaya kepiting soka tersebut menunjukkan nilai positif.

\section{DAFTAR PUSTAKA}

Chopin, T. 2006. Integrated Multi-Tropic Aquaculture. What It Is and Why You Should Care and Don't Confuse It with Policulture. Northern Aquaculture, Vol. 12(4).

DJPB. 2012. Polikultur Undang Windu, Bandeng dan Rumput Laut, dalam Bentuk Leftlet. Karawang: Balai layanan Usaha Produksi Perikanan Budidaya BLU Perikanan Budidaya. Karawang.

FAO. 2000. Code of Conduct for Responsible Fisheries.Food and Agricultural Organization, 41p. Roma. 
FAO. 2009. Integrated Multi-Tropik Aquaculture (IMTA) in Marine Temperate Water in D. Soto (ed), Integrated Marine Culture: A Global Review. FAO Fisheries and Aquaculture.

Haris. 2009. Akuakultur Berbasis Trofik Level: Revitalisasi untuk Ketahanan Pangan, Daya Saing Ekspor dan Kelestarian Lingkungan, dalam bentuk Powerpoint yang dipresentasikan dalam Seminar Peningkatan Produksi Budidaya Perikanan Provinsi Jambi. Dinas Kelautan dan Perikanan Provinsi Jambi, Jambi.

Hirata. 2002. Aquaculture Feed Naturally Low Productivity Small Environmental Impact of Aquaculture for Intensive Aquaculture (dalam bentuk Powerpoint). Kagoshima University. Jepang.
Pretty, J. 1995. Regenerative Agriculture: Policies And Practice for Sustainabiliti dan Self - Reliance. In. R. Ramirez. 1995. Participatory Learning and Communication Approach Managing Pluralism. http://www.fao.org/document/show_cdr, asp?url file=/DOCREP/W8827E/w8827e08.htm. diakses tanggal 9 Mei 2005.

Purnomo, A. 2005. Model Pengembangan Budidaya Berkelanjutan (dalam bentuk Powerpoint) yang dipresentasikan dalam Seminar Tentang Tambak Milenium.

Syahyuti. 2011. Gampang-Gampang Susah Mengorganisasikan Petani. Kajian Teori dan Praktik Sosiologi Lembaga dan Organisasi. IPB - Press. Bogor. 